\title{
Teaching Video NeuroImages: Facial myokymia and myorhythmia in anti-IgLON5 disease
}

\section{The bitten lip}

Elena Vetter, MD, David G. Olmes, MD, Ralf Linker, MD, and Frank Seifert, MD

Neurology ${ }^{\circledR}$ 2018;91:e1659. doi:10.1212/WNL.0000000000006388

A 79-year-old woman presented with an 8-month history of parasomnia and progressive bulbar syndrome with dysarthria, dysphagia, facial myokymia, and mandibular myorhythmia (video 1) resulting in biting scars of her lower lip. Brain MRI and EEG were unremarkable. CSF analysis showed intrathecal antibody synthesis and elevated tau $372 \mathrm{pg} / \mathrm{mL}(0-320 \mathrm{pg} / \mathrm{mL})$ and phospho-tau $54 \mathrm{pg} / \mathrm{mL}(0-50 \mathrm{pg} / \mathrm{mL})$. Antibodies against IgLON5 were highly positive (1: $1,000)$ in CSF and serum. Anti-IgLON5 disease was diagnosed. ${ }^{1}$ Recognition of bulbar symptoms with myokymia and myorhythmia as part of an anti-IgLON5 disease may be important to start early immunotherapy to prevent progression to neurodegeneration. ${ }^{2}$

\section{Author contributions}

Dr. Vetter: acquisition of data, analysis and interpretation of data, draft and review of the manuscript. Dr. Olmes: analysis and interpretation of data, review of the manuscript. Prof. Linker: critical revision of manuscript for intellectual content. Dr. Seifert: study supervision, analysis and interpretation of data, critical revision of manuscript for intellectual content.

\section{Acknowledgment}

The authors thank the patient for participation.

\section{Study funding}

No targeted funding reported.

\section{Disclosure}

The authors report no disclosures relevant to the manuscript. Go to Neurology.org/ $\mathrm{N}$ for full disclosures.

\section{References}

1. Sabater L, Gaig C, Gelpi E, et al. A novel non-rapid-eye movement and rapid-eye-movement parasomnia with sleep breathing disorder associated with antibodies to IgLON5. Lancet Neurol 2014;13:575-586.

2. Honorat JA, Komorowski L, Josephs KA, et al. IgLON5 antibody. Neurol Neuroimmunol Neuroinflamm 2017;4:385.
Correspondence

Dr. Vetter

elena.vetter@uk-erlangen.de

\section{MORE ONLINE}

○ Video

$\rightarrow$ Teaching Slides

links.lww.com/WNL/

A716 


\title{
Neurology
}

\author{
Teaching Video NeuroImages: Facial myokymia and myorhythmia in anti-IgLON5 \\ disease: The bitten lip \\ Elena Vetter, David G. Olmes, Ralf Linker, et al. \\ Neurology 2018;91; 1659 \\ DOI 10.1212/WNL.0000000000006388
}

This information is current as of October 22, 2018

\section{Updated Information \& Services}

References

Citations

Subspecialty Collections

Permissions \& Licensing

Reprints including high resolution figures, can be found at: http://n.neurology.org/content/91/17/e1659.full

This article cites 2 articles, 0 of which you can access for free at: http://n.neurology.org/content/91/17/e1659.full\#ref-list-1

This article has been cited by 1 HighWire-hosted articles: http://n.neurology.org/content/91/17/e1659.full\#\#otherarticles

This article, along with others on similar topics, appears in the following collection(s):

\section{All Movement Disorders}

http://n.neurology.org/cgi/collection/all_movement_disorders

Autoimmune diseases

http://n.neurology.org/cgi/collection/autoimmune_diseases

Parasomnias

http://n.neurology.org/cgi/collection/parasomnias

Information about reproducing this article in parts (figures,tables) or in its entirety can be found online at:

http://www.neurology.org/about/about_the_journal\#permissions

Information about ordering reprints can be found online:

http://n.neurology.org/subscribers/advertise

Neurology ${ }^{\circledR}$ is the official journal of the American Academy of Neurology. Published continuously since 1951, it is now a weekly with 48 issues per year. Copyright () 2018 American Academy of Neurology. All rights reserved. Print ISSN: 0028-3878. Online ISSN: 1526-632X.

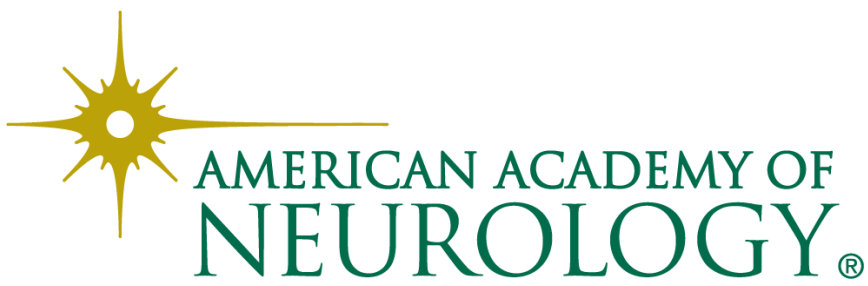

